\title{
Production of Sodium Dihydrogen Phosphate Using Sodium Chloride and Orthophosphoric Acid
}

\author{
Pham Minh Doan,* Nzihou Ange, and Sharrock Patrick \\ Université de Toulouse, Mines Albi, CNRS UMR 5302, Centre RAPSODEE, Campus Jarlard, F-81013 Albi, cedex 09, France
}

\begin{abstract}
Up-to-date, standard synthesis processes of sodium phosphates are based on the neutralization of orthophosphoric acid by sodium hydroxide or sodium carbonate. To the best of our knowledge, the reaction between sodium chloride and orthophosphoric acid has not yet been reported in the literature. This study demonstrated the feasibility of the synthesis of sodium dihydrogen phosphate by the reaction of sodium chloride with orthophosphoric acid. A detailed parametric study was done, wherein the influence of reaction temperature, air flow rate, water addition flow rate, and reaction time was investigated. As expected, the evacuation of hydrogen chloride $(\mathrm{HCl})$ was crucial for getting high conversion of $\mathrm{NaCl}$ to $\mathrm{HCl}$. The highest conversion of $\mathrm{NaCl}$ to $\mathrm{HCl}$ reached $91 \%$ after $24 \mathrm{~h}$ of synthesis reaction. Sodium dihydrogen phosphate $\left(\mathrm{NaH}_{2} \mathrm{PO}_{4}\right)$ was the main product. Pyrophosphate $\left(\mathrm{P}_{2} \mathrm{O}_{7}{ }^{4-}\right)$ was only formed at trace amounts, and any trace of trimetaphosphate $\left(\mathrm{P}_{3} \mathrm{O}_{9}{ }^{3-}\right)$ was observed.
\end{abstract}

\section{INTRODUCTION}

Phosphates include a large number of chemical products and can be divided into different categories: orthophosphates, linear polyphosphates, cyclic metaphosphates, and cross-linked phosphates. They are widely used in various applications such as fertilizer, ${ }^{1-3}$ food industries, ${ }^{3,4}$ energy, ${ }^{3,5,6}$ environment, ${ }^{7-12}$ catalysis, ${ }^{13-15}$ etc. Orthophosphoric acid is industrially produced from the dissolution of phosphate rocks by sulfuric acid. $^{16,17}$ The neutralization of orthophosphoric acid with a base forms the corresponding orthophosphate salts. On the other hand, most pyrophosphates and polyphosphates are generally obtained by the condensation of orthophosphates. For example, sodium trimetaphosphate ( $\mathrm{STM}, \mathrm{Na}_{3} \mathrm{P}_{3} \mathrm{O}_{9}$ ) is produced on an industrial scale by heating sodium dihydrogen phosphate $\left(\mathrm{NaH}_{2} \mathrm{PO}_{4}\right)$ at $500{ }^{\circ} \mathrm{C}$ for $5 \mathrm{~h}^{18-20}$

Among the large number of phosphate compounds, alkali orthophosphates appear as the most important ones, in particular for being used as fertilizers and food additives. ${ }^{3}$ As mentioned above, alkali orthophosphates are obtained by the neutralization of orthophosphoric acid and the corresponding alkali hydroxide, such as $\mathrm{NaOH}$. $\mathrm{NaOH}$ is industrially produced by the electrolysis of brine, the aqueous solution of sodium chloride. So, it is of interest to get sodium orthophosphates and sodium phosphates, directly from orthophosphoric acid and sodium chloride, as shown in eq 3.

Classical production of sodium dihydrogen phosphate:

$$
\begin{aligned}
& 2 \mathrm{NaCl}(\mathrm{aq})+2 \mathrm{H}_{2} \mathrm{O}(\mathrm{aq}) \rightarrow 2 \mathrm{NaOH}(\mathrm{aq})+\mathrm{H}_{2}(\mathrm{~g}) \\
& +\mathrm{Cl}_{2}(\mathrm{~g}) \Delta_{f} \mathrm{H}^{\circ}:+480.6 \mathrm{~kJ} \mathrm{~mol}^{-1} \\
& \mathrm{NaOH}(\mathrm{aq})+\mathrm{H}_{3} \mathrm{PO}_{4}(\mathrm{aq}) \rightarrow \mathrm{NaH}_{2} \mathrm{PO}_{4}(\mathrm{aq})+\mathrm{H}_{2} \mathrm{O}(\mathrm{aq}) \\
& \Delta_{f} H^{\circ}:-124.7 \mathrm{~kJ} \mathrm{~mol}^{-1}
\end{aligned}
$$

The studied process in this work:

$$
\begin{aligned}
& \mathrm{NaCl}(\mathrm{aq})+\mathrm{H}_{3} \mathrm{PO}_{4}(\mathrm{aq}) \rightarrow \mathrm{NaH}_{2} \mathrm{PO}_{4}(\mathrm{aq})+\mathrm{HCl}(\mathrm{aq}) \Delta_{f} \\
& H^{\circ}:-24.6 \mathrm{~kJ} \mathrm{~mol}^{-1}
\end{aligned}
$$

However, to the best of our knowledge, there has not yet been an industrial application of the direct reaction between orthophosphoric acid and sodium chloride. This seems to be the consequence of poor literature data on this reaction, with only some rare work at the laboratory scale reported. ${ }^{21,22}$ The first one described the synthesis of monoalkali or monoammonium orthophosphates $\left(\mathrm{MH}_{2} \mathrm{PO}_{4}\right.$, with $\mathrm{M}: \mathrm{K}, \mathrm{Na}$, and $\mathrm{NH}_{4}$ ) from the reaction of $\mathrm{MCl}$ with $\mathrm{H}_{3} \mathrm{PO}_{4}$ in the presence of an organic solvent such as $n$-octane, white sprit, kerosene, tetrachloroethane, etc. ${ }^{21}$ The reaction was carried out at 12$160{ }^{\circ} \mathrm{C}$ in order to form the $\mathrm{HCl}-\mathrm{H}_{2} \mathrm{O}$ azeotrope. The role of the organic solvent is probably for facilitating the separation of the $\mathrm{HCl}-\mathrm{H}_{2} \mathrm{O}$ azeotrope from the reaction mixture. Experiments have been done with both batch and continuous reactors which showed interesting results. The main drawbacks of this process were the presence of several steps (multisteps synthesis) and the use of an organic solvent.

Zhou et al. ${ }^{22}$ described the synthesis of $\mathrm{NaH}_{2} \mathrm{PO}_{4}$ and $\mathrm{Na}_{2} \mathrm{HPO}_{4}$ from $\mathrm{NaCl}$ and $\mathrm{H}_{3} \mathrm{PO}_{4}$ using an organic amine. This amine is not miscible with the aqueous phase and is for trapping $\mathrm{HCl}$ formed from the reaction of $\mathrm{NaCl}$ and $\mathrm{H}_{3} \mathrm{PO}_{4}$. Thus, the organic phase contains $\mathrm{HCl}$ while the aqueous phase contains $\mathrm{NaH}_{2} \mathrm{PO}_{4}$ or $\mathrm{Na}_{2} \mathrm{HPO}_{4}$. These two phases are easily separated by simple decantation. Crystals of $\mathrm{NaH}_{2} \mathrm{PO}_{4}$ or $\mathrm{Na}_{2} \mathrm{HPO}_{4}$ are obtained by cooling down the aqueous fraction. On the other hand, the organic solvent is regenerated by adding of ammonium hydroxide, which forms $\mathrm{NH}_{4} \mathrm{Cl}$ as a byproduct. By varying the organic amine, $\mathrm{Na}_{2} \mathrm{HPO}_{4}$ could be obtained, indicating that the process was performed for the conversion of the second proton of orthophosphoric acid. However, the main drawbacks of this process relate to the use of an organic amine, 
as well as the consumption of a non-negligible quantity of $\mathrm{NH}_{4} \mathrm{OH}$.

In this work, we demonstrated the feasibility of the synthesis of $\mathrm{NaH}_{2} \mathrm{PO}_{4}$ from $\mathrm{NaCl}$ and $\mathrm{H}_{3} \mathrm{PO}_{4}$ by a one-step synthesis process, using only water as a solvent.

\section{MATERIALS AND METHODS}

Sodium chloride powder with the volume-mean diameter $\left(d_{\mathrm{NaCl}}\right)$ of $375 \mu \mathrm{m}$ from Acros Organics and $85 \mathrm{wt} \%$ orthophosphoric acid from Merck were used. Both the reactants were pure analytical grade. Distilled water was also used for the synthesis reaction.

Three different glass reactors were used in this work (Figure 1). The first one $\left(N^{\circ} 1\right)$ was a $250 \mathrm{~mL}$ three-neck round-bottom
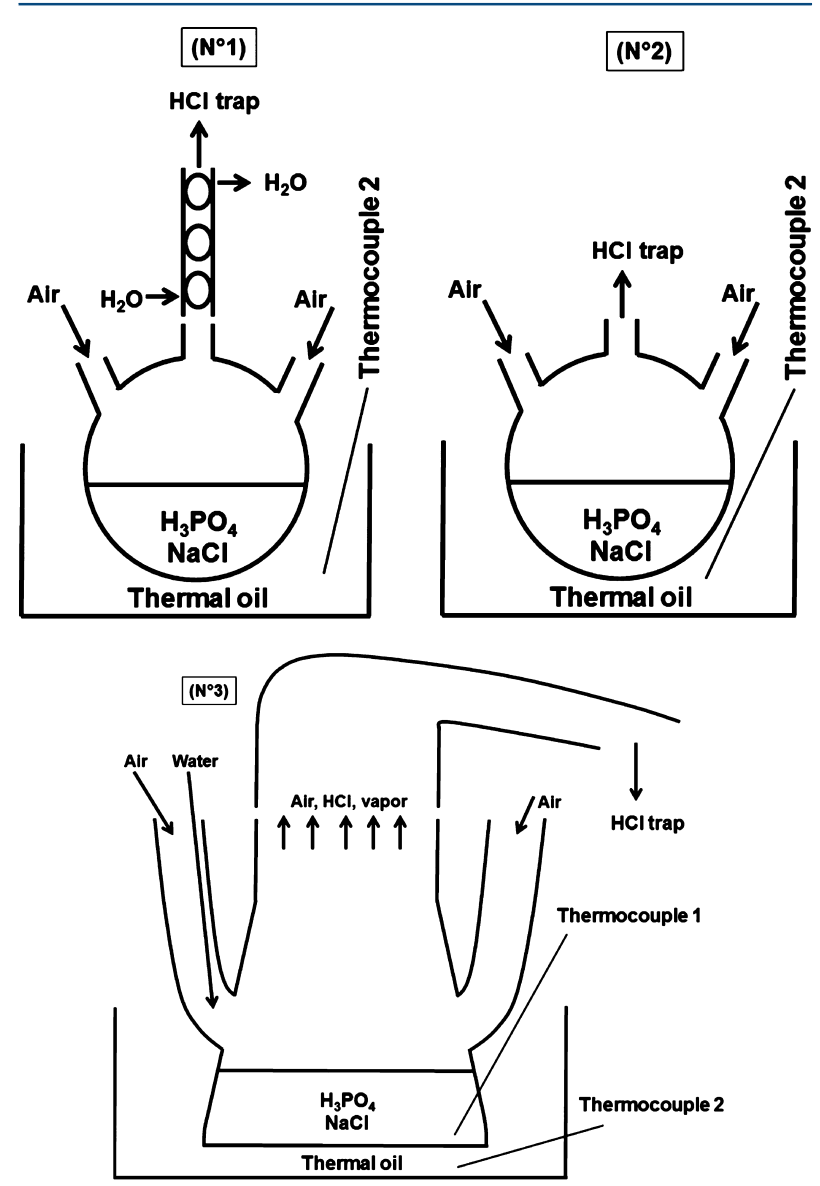

Figure 1. Illustration of three glass reactors used in this work.

flask connected with a vapor condenser. The second reactor $\left(N^{\circ} 2\right)$ was similar to the first one but without a vapor condenser. The third reactor $\left(N^{\circ} 3\right)$ was a $250 \mathrm{~mL}$ erlenmeyer flask modified by adding two identical necks.

The heating of the reaction medium was realized via a bath of thermal oil, which can be heated up to $300{ }^{\circ} \mathrm{C}$. The oil bath was heated by a heating plate, with the regulation of the temperature by thermocouple 2 inserted in the oil bath. For the reactor $N^{\circ} 3$, the temperature of the reaction mixture was monitored by thermocouple 1 .

For a given synthesis reaction, $20.45 \mathrm{~g}$ (or $0.35 \mathrm{~mol}$ ) of fine powder $\mathrm{NaCl}$ and $40.35 \mathrm{~g}$ of $85 \mathrm{wt} \% \mathrm{H}_{3} \mathrm{PO}_{4}$ (or $0.35 \mathrm{~mol}$ $\mathrm{H}_{3} \mathrm{PO}_{4}$ and $6.05 \mathrm{~g} \mathrm{H}_{2} \mathrm{O}$ ) were introduced into the reactor under stirring $(500 \mathrm{rpm})$. This corresponded to the initial molar ratio of sodium to orthophosphate equal to $1 / 1$. After heating the oil bath to the desired temperature between 80 and $130^{\circ} \mathrm{C}$, the glass reactor was immersed in this oil bath for starting the reaction. During the reaction, liquid water could be added with a controlled flow rate using a peristaltic pump through a neck of the reactors, as illustrated in Figure 1 (reactor $N^{\circ} 3$ ). An air flux passed over the surface of the reaction mixture, in order to evacuate $\mathrm{HCl}$-vapor mixture out of the reactor. This mixture was trapped into a water washing flask to prevent air pollution. The quantity of $\mathrm{Cl}^{-}$in the trap was analyzed by ion chromatography [Dionex IonPac AS $19(4 \times$ $250 \mathrm{~mm}$ ) column, conductivity detector]. This allows for calculating the conversion of $\mathrm{NaCl}$ to $\mathrm{HCl}$ by the following equation:

$$
X_{\mathrm{NaCl}}=\frac{n_{\mathrm{Cl}}^{f}}{n_{\mathrm{Cl}}^{i}} \times 100 \%
$$

with $n_{\mathrm{Cl}}^{i}$ the initial quantity of $\mathrm{NaCl}$ introduced into the reactor, and $n_{\mathrm{Cl}}^{f}$ the quantity of $\mathrm{Cl}$ evacuated to the trap.

At the end of the synthesis reaction, the final product in the reactor was completely dissolved and diluted with water before analysis by ion chromatography and by ICP-AES (HORIBA Jobin Yvon Ultima 2), in order to make mass balance. In this work, we have studied the influence of the following parameters on the conversion of synthesis: (1) the reaction temperature, (2) the air flow rate, (3) the water addition flow rate, (4) the reaction time, and (5) the vapor condensation.

\section{RESULTS AND DISCUSSION}

3.1. Reactor Validation. As mentioned above, three glass reactors were used in this work (Figure 1). The first tests were carried out under the same reaction conditions $\left(80{ }^{\circ} \mathrm{C}\right)$, in order to choose the highest performing reactor. The results are presented in Figure 2. The reactor $N^{\circ} 3$ showed the highest

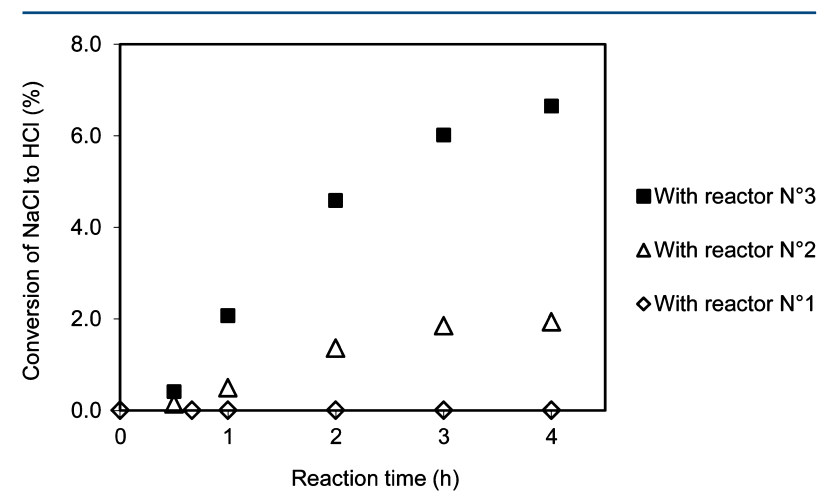

Figure 2. Comparison of three glass reactors. Reaction conditions: 500 rpm; $80{ }^{\circ} \mathrm{C}$; air flow rate, $120 \mathrm{~L} \mathrm{~h}^{-1}$; and water addition, $5 \mathrm{~g} \mathrm{~h}^{-1}$.

efficiency with $7 \%$ of $\mathrm{NaCl}$ conversion after $4 \mathrm{~h}$ of reaction. The reactor $N^{\circ} 2$ had much lower efficiency compared to the reactor $N^{\circ} 3$ with only $2 \%$ of conversion after $4 \mathrm{~h}$ of reaction and did not progress between 3 and $4 \mathrm{~h}$ of reaction. The reactor $N^{\circ} 1$ had the lowest efficiency with only trace amounts of $\mathrm{HCl}$ formed after $4 \mathrm{~h}$ of reaction.

$\mathrm{HCl}$ was formed according to eq 3 and needed to be evacuated out of the reaction mixture to favor the formation of the desired product. For the reactor $N^{\circ} 1, \mathrm{HCl}$ and vapor were condensed and returned to the reaction medium. So, only trace 


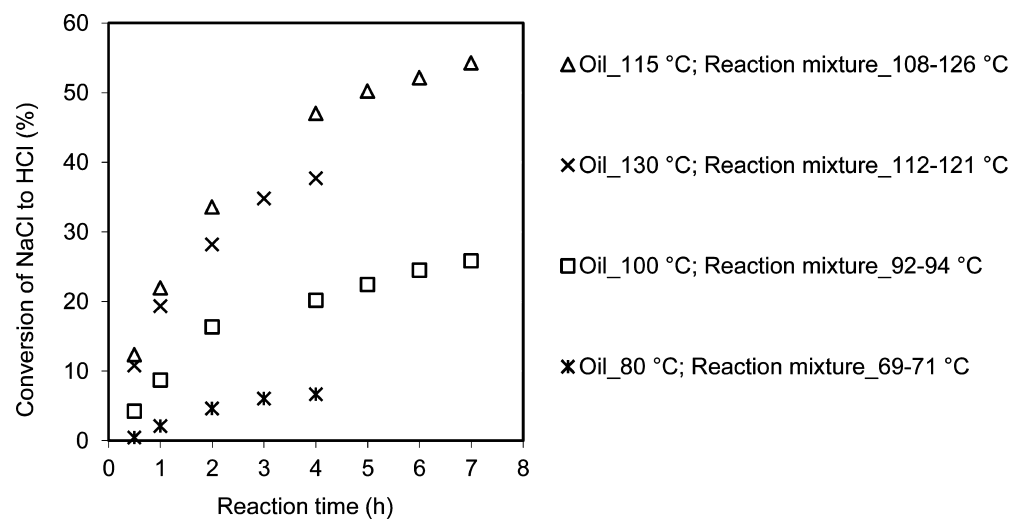

Figure 3. Influence of reaction temperature on the conversion of $\mathrm{NaCl}$ to $\mathrm{HCl}$. Reaction conditions: air flow rate, $120 \mathrm{~L} \mathrm{~h}^{-1}$; $500 \mathrm{rpm}$; and flow rate of water addition, $5 \mathrm{~g} \mathrm{~h}^{-1}$.

amounts of $\mathrm{HCl}$ was found in the trap using this reactor. For the reaction $\mathrm{N}^{\circ} 2, \mathrm{HCl}$ could get out of the reactor but the section of the neck for $\mathrm{HCl}$ outlet was small compared to the reactor walls. This made the evacuation of $\mathrm{HCl}$ difficult. We observed the formation of aqueous $\mathrm{HCl}$ drops on the reactor walls which returned to the reaction mixture during the reaction with the reactor $N^{\circ} 2$. On the other hand, the reactor $N^{\circ} 3$ favored the evaporation of $\mathrm{HCl}$-vapor mixture thanks to its large outlet. So, the reactor $N^{\circ} 3$ was thereafter used for other studies.

3.2. Influence of the Reaction Temperature. The temperature of the oil bath was controlled using the thermocouple 2 (Figure 1). On the other hand, the temperature of the reaction mixture was monitored by the thermocouple 1. Figure 3 shows the influence of the reaction temperature on the conversion of $\mathrm{NaCl}$ to $\mathrm{HCl}$. When the oil bath was kept at $80^{\circ} \mathrm{C}$, we observed that the temperature of the reaction mixture reached $69-71^{\circ} \mathrm{C}$, leading to low efficiency of the process (less than $10 \%$ of conversion after $4 \mathrm{~h}$ of reaction time). The increase of the temperature of the oil bath to 100 , 115 , and $130{ }^{\circ} \mathrm{C}$ allowed increasing the performance of the process. The highest performance was found for $115{ }^{\circ} \mathrm{C}$ with $54 \%$ of conversion after $7 \mathrm{~h}$ of reaction time. In fact, when the temperature of the oil bath was set at $115^{\circ} \mathrm{C}$, the temperature of the reaction mixture varied in the range of $108-126{ }^{\circ} \mathrm{C}$, which is close to the boiling temperature of the $\mathrm{HCl}-\mathrm{H}_{2} \mathrm{O}$ azeotrope $\left(108.6{ }^{\circ} \mathrm{C}\right)$. So this facilitates the elimination of $\mathrm{HCl}$ from the reaction mixture. A thermodynamic calculation of Gibbs energy minimization can help to suggest how the azeotrope can be best used to get $\mathrm{HCl}$ out of the reactor. However, the water content in the reaction mixture varied at a given reaction time. So, we could not calculate Gibbs energy minimization for such a system. The temperature of the oil bath of $130{ }^{\circ} \mathrm{C}$ was slightly less efficient than $115{ }^{\circ} \mathrm{C}$ because it overheated and dried the reaction mixture too much and thus limited the evaporation of the $\mathrm{HCl}-\mathrm{H}_{2} \mathrm{O}$ mixture.

3.3. Influence of the Air Flow Rate. To evacuate the HCl$\mathrm{H}_{2} \mathrm{O}$ mixture out of the reactor, an air circulation on the surface of the reaction mixture was applied. The influence of the air flow rate is presented in Figure 4. The increase of the air flow rate from 60 to $120 \mathrm{~L} \mathrm{~h}^{-1}$ increased the efficiency of the process. But there was no gain by passing the air flow rate from 120 to $240 \mathrm{~L} \mathrm{~h}^{-1}$. So the air flow rate of $120 \mathrm{~L} \mathrm{~h}^{-1}$ was chosen for the next tests.

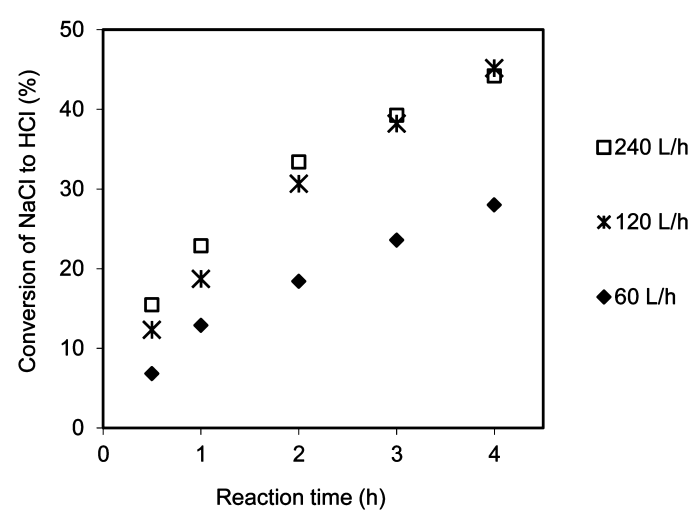

Figure 4. Influence of the air flow rate on the conversion of $\mathrm{NaCl}$ to $\mathrm{HCl}$. Reaction conditions: temperature of the oil bath, $115{ }^{\circ} \mathrm{C}$; 500 $\mathrm{rpm}$; and flow rate of water addition, $5 \mathrm{~g} \mathrm{~h}^{-1}$.

3.4. Influence of the Water Addition Flow Rate. The evacuation of $\mathrm{HCl}$ is the key parameter for the advancement of the reaction. Since $\mathrm{HCl}$ forms with water, an azeotrope containing 20.2 wt \% of $\mathrm{HCl}$ which has the boiling point at $108.6{ }^{\circ} \mathrm{C}$, the rate of water addition, the temperature of the reaction mixture, and the air flow rate need to be controlled to favor the formation of this azeotrope. Figure 5 shows the influence of the water addition flow rate to the reaction mixture

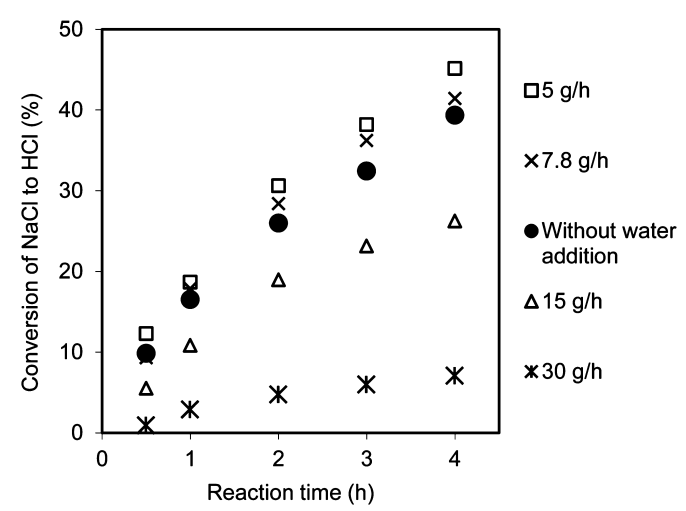

Figure 5. Influence of the flow rate of water addition on the conversion of $\mathrm{NaCl}$ to $\mathrm{HCl}$. Reaction conditions: temperature of the oil bath, $115{ }^{\circ} \mathrm{C}$; $500 \mathrm{rpm}$; and air flow rate, $120 \mathrm{~L} \mathrm{~h}^{-1}$. 

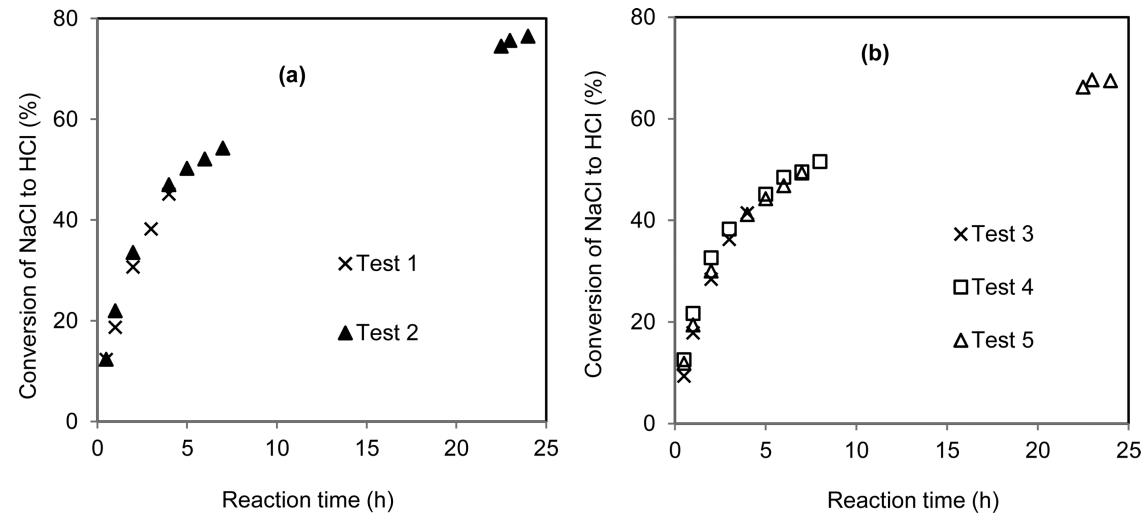

Figure 6. Influence of the reaction time on the conversion of $\mathrm{NaCl}$ to $\mathrm{HCl}$. Reaction conditions: temperature of the oil bath, $115{ }^{\circ} \mathrm{C}$; $500 \mathrm{rpm}$; air flow rate, $120 \mathrm{~L} \mathrm{~h}^{-1}$; and flow rate of water addition (a) $5 \mathrm{~g} \mathrm{~h}^{-1}$ or (b) $7.8 \mathrm{~g} \mathrm{~h}^{-1}$.
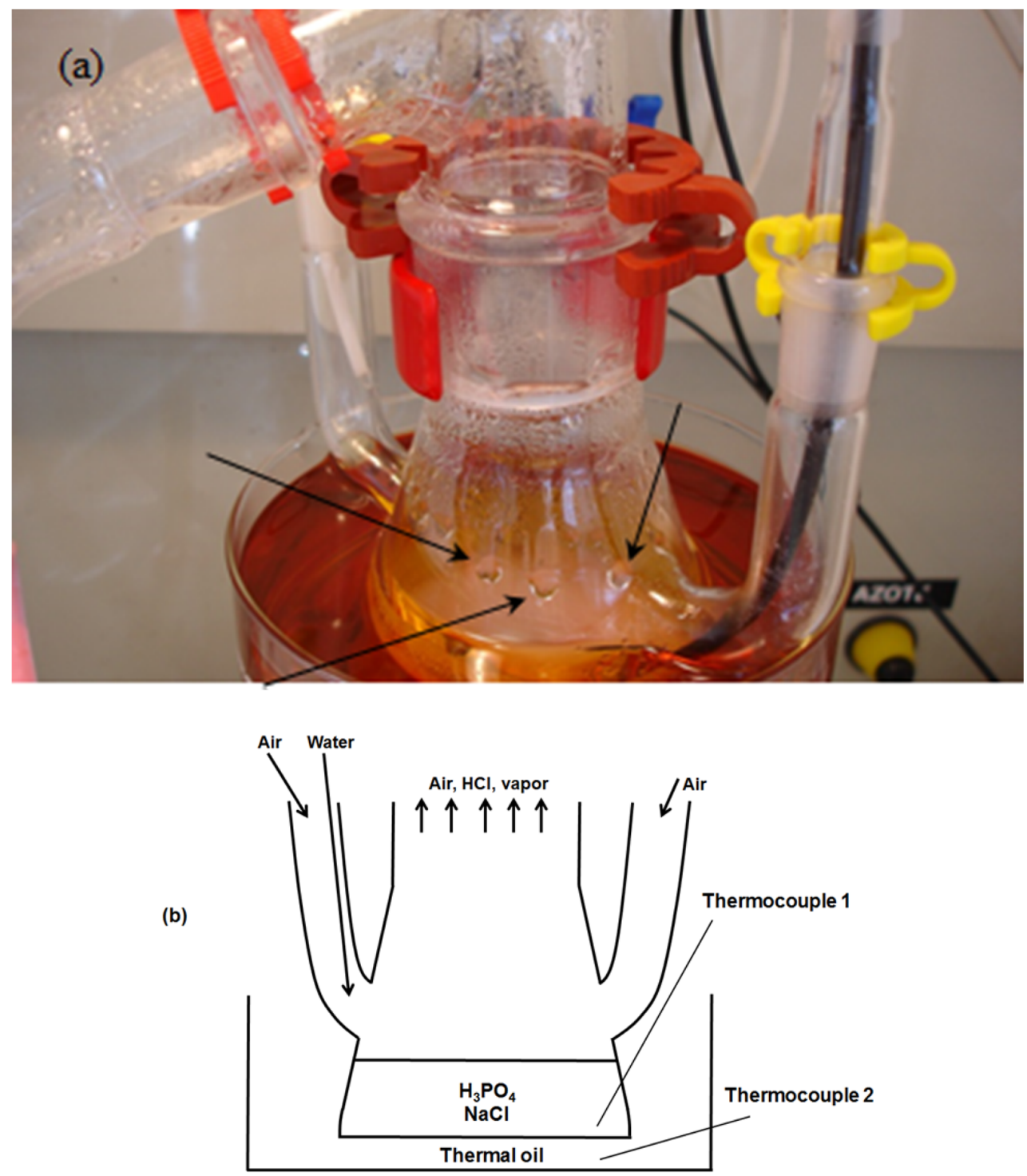

Figure 7. (a) Illustration of $\mathrm{HCl}$ condensation during the synthesis reaction with $\mathrm{HCl}$ trap and (b) reactor without $\mathrm{HCl}$ trap.

when keeping constant the temperature of the thermal oil bath at $115^{\circ} \mathrm{C}$ and the air flow rate at $120 \mathrm{~L} \mathrm{~h}^{-1}$, which were the most favorable conditions for the reaction. The increase of the water addition flow rate was not favorable for the reaction 
under the present experimental conditions. The best results were obtained with the flow rate of $5 \mathrm{~g} \mathrm{~h}^{-1}$ (or about $0.08 \mathrm{~mL}$ $\mathrm{min}^{-1}$ ). This is also the minimum working flow rate of the pump that we used. Another experiment was done, without adding water. The results were similar compared to those of adding $5 \mathrm{~g}$ of water per $\mathrm{h}$ at the beginning of the reaction. Then, the reaction slowed down because there was no more water in the medium. We consider that the best flow rate of water addition was $5 \mathrm{~g} \mathrm{~h}^{-1}$.

3.5. Influence of the Reaction Time and Reproducibility of the Process. Using the reactor $N^{\circ} 3$, the reaction was not finished after $4 \mathrm{~h}$ of reaction. Thus, different tests were carried out for longer reaction times, up to $24 \mathrm{~h}$. The optimal experimental conditions found above were used, including the following: temperature of the oil bath, $115{ }^{\circ} \mathrm{C}$; $500 \mathrm{rpm}$; air flow rate, $120 \mathrm{~L} \mathrm{~h}^{-1}$; and rate of water addition, 5 or $7.8 \mathrm{~g} \mathrm{~h}^{-1}$. The reproducibility of the process was also checked by repeating the reaction several times. Figure 6 shows the results obtained.

For the water addition of $5 \mathrm{~g} \mathrm{~h}^{-1}$, the conversion of $\mathrm{NaCl}$ to $\mathrm{HCl}$ continued up to $24 \mathrm{~h}$ of reaction. The conversion profile suggests that the reaction could evolve still. The conversion of $76.5 \%$ was obtained after $24 \mathrm{~h}$ (test 1, Figure 6a). For the water addition of $7.8 \mathrm{~g} \mathrm{~h}^{-1}$, similar results were obtained but the reaction seemed to strongly slow down, taking into account the conversion profile of $\mathrm{NaCl}$ to $\mathrm{HCl}$ (test 3, Figure 6b). The conversion of $\mathrm{NaCl}$ to $\mathrm{HCl}$ reached $67.5 \%$ after $24 \mathrm{~h}$ of reaction. For both the water addition rates, tests of reproducibility allowed confirming that the process was well repeatable (test 2, Figure 6a and tests 4 and 5, Figure 6b).

3.6. Improvement of the Performance of the Synthesis Process. $\mathrm{HCl}$ trap allowed channeling and recovering $\mathrm{HCl}$ vapor. But vapor condensation took place during the reaction, as illustrated in Figure 7a. In fact, the head of the reactor was not heated, which caused the condensation of the $\mathrm{HCl}$-vapor mixture. This condensation is dramatic because it sent $\mathrm{HCl}$ back to the reaction mixture and thus slowed down the reaction.

To the reduction of this condensation, a parametric study was carried out by removing the $\mathrm{HCl}$ trap, as illustrated in Figure $7 \mathrm{~b}$. In parallel, the consistency of the reaction mixture was also adjusted by manual water addition. In fact, after the first hours of reaction time ( 0 to $13 \mathrm{~h}$ ), about $50-70 \%$ of orthophosphoric acid were converted into sodium phosphates. The reaction mixture partially lost its initial consistency and could be dried under heating and air flux. This prevented the contact between $\mathrm{Cl}^{-}$anions and protons $\mathrm{H}^{+}$inside the reaction mixture. Manual water addition every hour or every $30 \mathrm{~min}$ again allowed for the homogenization of the reaction mixture. After each homogenization, the reaction mixture was progressively dried under heating and air flux before the next manual water addition. By this method, the reaction mixture could reach the composition of $\mathrm{HCl}-\mathrm{H}_{2} \mathrm{O}$ azeotrope, which favors the elimination of $\mathrm{HCl}$ from the reaction mixture. Note that with the reaction time, the content of chloride in the reaction mixture decreased and the quantity of water required for getting the composition of $\mathrm{HCl}-\mathrm{H}_{2} \mathrm{O}$ azeotrope changed. Manual water addition was used for adapting to this evolution. Table 1 summarizes the reaction conditions of this parametric study.

Because $\mathrm{HCl}$ was not trapped, we could only analyze the chloride content remaining in the final product, recovered at the end of the reaction $(24 \mathrm{~h})$. Figure 8 shows the conversion
Table 1. Reaction Conditions for the Synthesis of $\mathrm{NaH}_{2} \mathrm{PO}_{4}$ from $\mathrm{NaCl}$ and $\mathrm{H}_{3} \mathrm{PO}_{4}$ using Reactor $\mathrm{N}^{\circ} 3$ without $\mathrm{HCl}$ Trap; the Mean Diameter $d_{50}$ of $\mathrm{NaCl}$ was $375 \mu \mathrm{m}$ for All Experiences, except for the Experience G

\begin{tabular}{|c|c|c|}
\hline experiment & $\begin{array}{l}\text { continuous addition of } \\
\text { water by the peristaltic } \\
\text { pump }\left(\mathrm{g} \mathrm{h}^{-1}\right)\end{array}$ & manual water addition \\
\hline A & 8 & without manual water addition \\
\hline B & 8 & $\begin{array}{l}10 \mathrm{~g} \text { every hour between } 8 \text { and } 24 \mathrm{~h} \\
\text { of reaction }\end{array}$ \\
\hline $\mathrm{C}$ & 15 & $\begin{array}{l}10 \mathrm{~g} \text { every hour between } 8 \text { and } 24 \mathrm{~h} \\
\text { of reaction }\end{array}$ \\
\hline $\mathrm{D}$ & 15 & $\begin{array}{l}10 \mathrm{~g} \text { every hour between } 13 \text { and } 24 \\
\mathrm{~h} \text { of reaction }\end{array}$ \\
\hline $\mathrm{E}$ & 15 & $\begin{array}{l}7 \mathrm{~g} \text { every hour between } 13 \text { and } 24 \mathrm{~h} \\
\text { of reaction }\end{array}$ \\
\hline $\mathrm{F}$ & 15 & $\begin{array}{l}5 \mathrm{~g} \text { every } 30 \mathrm{~min} \text { between } 13 \text { and } 24 \\
\mathrm{~h} \text { of reaction }\end{array}$ \\
\hline G & 15 & $\begin{array}{l}\text { similar reaction conditions to D but } \\
\text { with } \mathrm{NaCl} \text { of } d_{50} \text { of } 78 \mu \mathrm{m} \text { instead } \\
\text { of } 375 \mu \mathrm{m}\end{array}$ \\
\hline
\end{tabular}

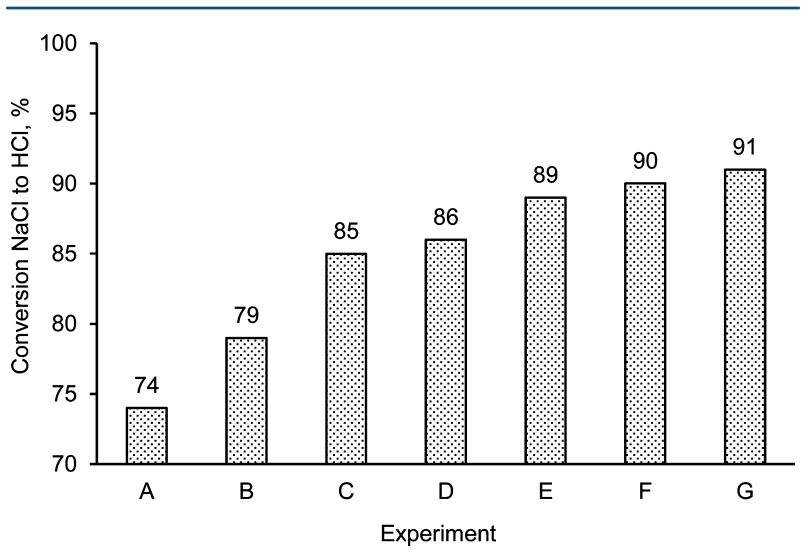

Figure 8. One-step synthesis of $\mathrm{NaH}_{2} \mathrm{PO}_{4}$ from $\mathrm{NaCl}$ and $\mathrm{H}_{3} \mathrm{PO}_{4}$ at atmospheric pressure and without the $\mathrm{HCl}$ trap. Reaction conditions: $500 \mathrm{rpm} ; 24 \mathrm{~h}$ of reaction; Thermal oil's temperature, $145{ }^{\circ} \mathrm{C}$; and water additions, see Table 1.

of $\mathrm{NaCl}$ to $\mathrm{HCl}$ after $24 \mathrm{~h}$ of reaction. The manual water addition (10 g every hour within 8-24 h of reaction) allowed for the increasing performance of the process from $74 \%$ to $79 \%$ (experiment A vs experiment B). The increase of water addition flow rate by the peristaltic pump from 8 to $15 \mathrm{~g} \mathrm{~h}^{-1}$ led to the increase of $\mathrm{NaCl}$ conversion from 79 to $86 \%$ (experiment $\mathrm{B}$ vs experiments $\mathrm{C}$ and $\mathrm{D}$ ). When the manual water addition was reduced to 7 instead of $10 \mathrm{~g}$ every hour, the performance slightly increased from 86 to $89 \%$ (experiment D vs experiment E). Manually adding $5 \mathrm{~g}$ of water every 30 min allowed for $90 \%$ conversion of $\mathrm{NaCl}$ to $\mathrm{HCl}$ (experiment $\mathrm{F}$ ). Finally, the use of $\mathrm{NaCl}$ powder having small particles $\left(d_{50}\right.$ of $\left.78 \mu \mathrm{m}\right)$ associated with the manual water addition of $10 \mathrm{~g}$ every hour led to the conversion of $91 \%$ (experiment G). This was also the best performance obtained in this work.

3.7. Analysis of the Final Product. Final product of each test described above was analyzed by ion chromatography and by ICP-AES. At the end of the reaction, the reaction mixture was dissolved with water to form homogeneous aqueous solution. This dissolution took place within less than $1 \mathrm{~min}$ under stirring. The resulting solution was quickly analyzed by ion chromatography for determining chloride $\left(\mathrm{Cl}^{-}\right)$, orthophosphate $\left(\mathrm{PO}_{4}{ }^{3-}\right)$, pyrophosphate $\left(\mathrm{P}_{2} \mathrm{O}_{7}{ }^{4-}\right)$, and trimetaphos- 
phate $\left(\mathrm{P}_{3} \mathrm{O}_{9}{ }^{3-}\right)$ species and by ICP-AES for determining sodium and phosphorus. As an example, Table 2 summarizes the analysis results obtained with the final product from experiment $\mathrm{G}$ in Figure 8.

Table 2. Analysis of Final Product of Experiment G in Figure 8 by Ion Chromatography and by ICP-AES

\begin{tabular}{|c|c|c|c|}
\hline \multirow{2}{*}{$\begin{array}{l}\text { product } \\
\text { composition of the initial } \\
\text { reaction mixture }\end{array}$} & \multicolumn{2}{|c|}{ species or element analyzed } & \multirow{2}{*}{$\frac{\begin{array}{c}\text { amount } \\
(\mathrm{mmol})\end{array}}{350}$} \\
\hline & $\begin{array}{l}\text { orthophosphate initially } \\
\text { introduced into the } \\
\text { reactor }\end{array}$ & $\mathrm{PO}_{4}{ }^{3-}{ }_{(i)}$ & \\
\hline & $\begin{array}{l}\text { chloride initially introduced } \\
\text { into the reactor }\end{array}$ & $\mathrm{Cl}_{(i)}^{-}$ & 350 \\
\hline & $\begin{array}{l}\text { sodium initially introduced } \\
\text { into the reactor }\end{array}$ & $\mathrm{Na}^{+}{ }_{(i)}$ & 350 \\
\hline \multirow[t]{4}{*}{$\begin{array}{l}\text { analysis of the final product } \\
\text { by ion chromatography }\end{array}$} & $\begin{array}{l}\text { chloride remaining in the } \\
\text { reactor }\end{array}$ & $\mathrm{Cl}^{-}(f)$ & 32 \\
\hline & $\begin{array}{l}\text { orthophosphate remaining } \\
\text { in the reactor }\end{array}$ & $\mathrm{PO}_{4}{ }^{3-}(f)$ & 347 \\
\hline & $\begin{array}{l}\text { pyrophosphate formed in } \\
\text { the reactor }\end{array}$ & $\mathrm{P}_{2} \mathrm{O}_{7}^{4-}(f)$ & 2 \\
\hline & $\begin{array}{l}\text { tripolyphosphate remaining } \\
\text { in the reactor }\end{array}$ & $\mathrm{P}_{3} \mathrm{O}_{9}{ }^{3-}{ }_{(f)}$ & 0 \\
\hline \multirow[t]{2}{*}{$\begin{array}{l}\text { analysis of the final product } \\
\text { by ICP-AES }\end{array}$} & $\begin{array}{l}\text { sodium remaining in the } \\
\text { reactor }\end{array}$ & $\mathrm{Na}_{(f)}$ & 349 \\
\hline & $\begin{array}{l}\text { total phosphorus in the } \\
\text { reactor }\end{array}$ & $P_{\text {(total) }}$ & 351 \\
\hline
\end{tabular}

Table 2 shows that the quantity of sodium and phosphorus in the final product analyzed by ICP $\left[\mathrm{Na}_{(f)}\right.$ and $\left.\mathrm{P}_{(\text {total })}\right]$ reached the initial quantity of sodium and phosphorus introduced in the reactor $\left[\mathrm{PO}_{4}{ }^{3-}{ }_{(\mathrm{i})}\right.$ and $\mathrm{Na}^{+}{ }_{(\mathrm{i})}$, respectively]. So, the mass balance was good for sodium and phosphorus. For chlorine, the mass balance could not be done for this experiment because $\mathrm{HCl}$ vapor was not trapped. But for all other experiments using $\mathrm{HCl}$ trap, the mass balance was also good (for chlorine). About the distribution of phosphorus-containing products, trimetaphosphate $\left(\mathrm{P}_{3} \mathrm{O}_{9}{ }^{3-}\right)$ was not observed. In fact, this product is formed at high temperature. ${ }^{20}$ Pyrophosphate $\left(\mathrm{P}_{2} \mathrm{O}_{7}{ }^{4-}\right)$ was only formed at trace amount $(2 \mathrm{mmol}$ or $0.6 \%$ of the initial quantity of orthophosphoric acid used). Orthophosphate $\left(\mathrm{PO}_{4}{ }^{3-}\right)$ was the principal phosphorus-containing product of the reaction $(347 \mathrm{mmol}$ or $99 \%$ of the initial quantity of orthophosphoric acid used).

From the results in Table 2, the composition of the final product of the experiment $\mathrm{G}$ in Figure 8 was proposed. Taking into account the fact that the initial reaction mixture contained $350 \mathrm{mmol}$ of $\mathrm{NaCl}$ and $350 \mathrm{mmol}$ of $\mathrm{H}_{3} \mathrm{PO}_{4}$, this product may contain the following components: (1) $31 \mathrm{mmol}$ of unreacted $\mathrm{NaCl}$ ( $9 \%$ of the initial quantity introduced into the reactor). (2) $31 \mathrm{mmol}$ of unreacted $\mathrm{H}_{3} \mathrm{PO}_{4}$ and $316 \mathrm{mmol}$ of $\mathrm{NaH}_{2} \mathrm{PO}_{4}$ corresponding to $347 \mathrm{mmol} \mathrm{PO}_{4}{ }^{3-}$. We considered that the quantity of unreacted $\mathrm{H}_{3} \mathrm{PO}_{4}$ was equal to the quantity of chloride remaining in the reaction mixture $(31 \mathrm{mmol})$. $\mathrm{NaH}_{2} \mathrm{PO}_{4}$ must be the main orthophosphate sodium because under acidic $\mathrm{pH}$ of the reaction, $\mathrm{H}_{3} \mathrm{PO}_{4}$ and $\mathrm{H}_{2} \mathrm{PO}_{4}{ }^{-}$are the main orthophosphate species, and the presence of $\mathrm{HPO}_{4}{ }^{2-}$ and $\mathrm{PO}_{4}{ }^{3-}$ must be negligible. ${ }^{23}$ (3) $2 \mathrm{mmol}$ of $\mathrm{P}_{2} \mathrm{O}_{7}{ }^{2-}$, which suggest the formation of $\mathrm{Na}_{2} \mathrm{H}_{2} \mathrm{P}_{2} \mathrm{O}_{7}$. This product could be formed by the condensation of $\mathrm{NaH}_{2} \mathrm{PO}_{4}$.

Figure 9a sketches the composition of the final product recovered from the experiment $G$ in Figure 8. As previously mentioned, this product was already dissolved in water for ion chromatography and ICP-AES analyses. This solution was later evaporated at room temperature and atmospheric pressure under an extractor hood for the crystallization step. Figure $9 \mathrm{~b}$ shows the crystals obtained from this evaporation. This product was slightly humid because of the presence of unreacted $\mathrm{H}_{3} \mathrm{PO}_{4}$ (9\%).

In summary, this work investigated the direct reaction of sodium chloride with orthophosphoric acid. The first objective was to design an alternative to the conventional industrial production of sodium phosphates from orthophosphoric acid and sodium hydroxide or sodium carbonate. From a technical point of view, sodium chloride could react with orthophosphoric acid at moderate temperature, and high conversion and high selectivity in sodium dihydrogen phosphate $\left(\mathrm{NaH}_{2} \mathrm{PO}_{4}\right)$ could be obtained. Evaluating the economic viability of this process is further necessary. But it is a complex task which requires multiple criteria and was not the first objective of this study. Thus, we report hereafter some general features about the present process considered, compared to the conventional production way: (1) the reaction of $\mathrm{NaOH}$ with $\mathrm{H}_{3} \mathrm{PO}_{4}$ is exothermic $\left(\Delta_{f} H^{\circ}:-124.7 \mathrm{~kJ} \mathrm{~mol}^{-1}\right)$, but it is carried out at a temperature around $80-100{ }^{\circ} \mathrm{C}$ on an industrial scale. The reaction of $\mathrm{NaCl}$ and $\mathrm{H}_{3} \mathrm{PO}_{4}$ is also slightly exothermic $\left(\Delta_{f} \mathrm{H}^{\circ}\right.$ : $-24.6 \mathrm{~kJ} \mathrm{~mol}^{-1}$ ) and needs a reaction temperature around 115 ${ }^{\circ} \mathrm{C}$. So the difference of energy for heating the reaction is small. However, $\mathrm{NaOH}$ is industrially produced by electrolysis of $\mathrm{NaCl}$ aqueous solution, which is very endothermic $\left(\Delta_{f} H^{\circ}:+\right.$ $480.6 \mathrm{~kJ} \mathrm{~mol}^{-1}$ ). So, the energy balance must take into account this electrolysis step, as well as the utility of the final products and byproducts of each synthesis method. The electrolysis of $\mathrm{NaCl}$ solution produces $\mathrm{H}_{2}$ and $\mathrm{Cl}_{2}$ as byproducts, while the direct reaction of $\mathrm{NaCl}$ and $\mathrm{H}_{3} \mathrm{PO}_{4}$ produces $\mathrm{HCl}$ as the only byproduct. (2) Conventional production of $\mathrm{NaH}_{2} \mathrm{PO}_{4}$ from $\mathrm{H}_{3} \mathrm{PO}_{4}$ and $\mathrm{NaOH}$ must be instantaneous at $80-100{ }^{\circ} \mathrm{C}$, while the reaction of $\mathrm{NaCl}$ with $\mathrm{H}_{3} \mathrm{PO}_{4}$ needed a long reaction time as observed in the present study. However, as mentioned above, $\mathrm{NaOH}$ is produced from $\mathrm{NaCl}$ by the specific
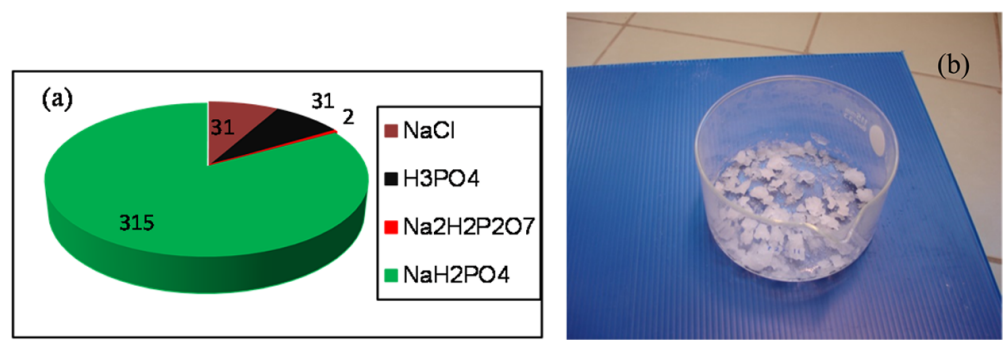

Figure 9. (a) Composition (mmol) of the final product obtained by the experiment $\mathrm{G}$ in Figure 8 and (b) illustration of the solid obtained after crystallization of this product. 
electrolysis process. The cost and impact of $\mathrm{NaOH}$ production must be included into the viability evaluation. (3) The reaction of $\mathrm{NaCl}$ and $\mathrm{H}_{3} \mathrm{PO}_{4}$ generates $\mathrm{HCl}$ as the byproduct, which is corrosive. But technological solution is now available for such a process. Strong acids such as $\mathrm{HCl}, \mathrm{HNO}_{3}$, and $\mathrm{H}_{2} \mathrm{SO}_{4}$ are largely produced on the industrial scale. So, the design of a reactor adapted to the presence of $\mathrm{HCl}$ must be possible.

\section{CONCLUSIONS}

For the first time, we were successful in the synthesis of sodium orthophosphate from the reaction of $\mathrm{NaCl}$ with orthophosphoric acid under moderate conditions. The reaction was studied in the aqueous medium, without organic solvent. The evacuation of $\mathrm{HCl}$ was found to be crucial for the reaction. This evacuation could be controlled by different parameters including: reactor geometry, reaction temperature, air flow rate, water addition, and reaction time. The highest conversion of $\mathrm{NaCl}$ to $\mathrm{HCl}$ obtained in this work reached $91 \%$ after $24 \mathrm{~h}$ of reaction.

Further work will be concentrated on the optimization of the synthesis process to get higher elimination yield of chloride, as well as on the competition of the present process versus standard neutralization of $\mathrm{H}_{3} \mathrm{PO}_{4}$ by $\mathrm{NaOH}$ or $\mathrm{Na}_{2} \mathrm{CO}_{3}$.

\section{AUTHOR INFORMATION}

\section{Corresponding Author}

*E-mail: doan.phamminh@mines-albi.fr. Tel: +33563493258. Fax: +33563493243 .

\section{Notes}

The authors declare no competing financial interest.

\section{ACKNOWLEDGMENTS}

The authors gratefully acknowledge colleagues at the RAPSODEE centre for technical help.

\section{REFERENCES}

(1) Walan, P.; Davidsson, S.; Johansson, S.; Höök, M. Phosphate rock production and depletion: Regional disaggregatedmodeling and global implications. Resour. Conserv. Recy. 2014, 93, 178-187.

(2) Ahmad, N. N. R.; Fernando, W. J. N.; Uzir, M. H. Parametric evaluation using mechanistic model for release rate of phosphate ions from chitosancoated phosphorus fertiliser pellets. Biosyst. Eng. 2015, $129,78-86$

(3) Kulakovskaya, T. V.; Vagabov, V. M.; Kulaev, I. S. Inorganic polyphosphate in industry, agriculture and medicine: Modern state and outlook. Process Biochem. 2012, 47, 1-10.

(4) Capuano, E.; Van der Veer, G.; Verheijen, P. J. J.; Heenan, S. P.; Van de Laak, L. F. J.; Koopmans, H. B. M.; Van Ruth, S. M. Comparison of a sodium-based and a chloride-based approach for the determination of sodium chloride content of processed foods in the Netherlands. J. Food Compos. Anal. 2013, 31, 129-136.

(5) Grolleau, S.; Delaille, A.; Gualous, H.; Gyan, P.; Revel, R.; Bernard, J.; Redondo-Iglesias, E.; Peter, J. Calendar aging of commercial graphite $/ \mathrm{LiFePO}_{4}$ cell-Predicting capacity fade under time dependent storage conditions. J. Power Sources 2014, 255, 450458.

(6) Zhang, W. J. Structure and performance of $\mathrm{LiFePO}_{4}$ cathode materials: A review. J. Power Sources 2011, 196, 2962-2970.

(7) Pham Minh, D.; Rio, S.; Sharrock, P.; Sebei, H.; Lyczko, N.; Tran, N. D.; Raii, M.; Nzihou, A. Hydroxyapatite starting from calcium carbonate and orthophosphoric acid: synthesis, characterization, and applications. J. Mater. Sci. 2014, 49, 4261-4269.

(8) Pham Minh, D.; Tran, N. D.; Nzihou, A.; Sharrock, P. Calcium phosphate based materials starting from calcium carbonate and orthophosphoric acid for the removal of lead(II) from an aqueous solution. Chem. Eng. J. 2014, 243, 280-288.

(9) Pham Minh, D.; Sebei, H.; Nzihou, A.; Sharrock, P. Apatitic calcium phosphates: Synthesis, characterization and reactivity in the removal of lead(II) from aqueous solution. Chem. Eng. J. 2012, 198199, 180-190.

(10) Pham Minh, D.; Tran, N. D.; Nzihou, A.; Sharrock, P. Hydroxyapatite gel for the improved removal of $\mathrm{Pb}^{2+}$ ions from aqueous solution. Chem. Eng. J. 2013, 232, 128-138.

(11) Raii, M.; Pham Minh, D.; Escudero Sanz, F. J.; Nzihou, A. Lead and cadmium removal from aqueous solution using an industrial gypsum by-product. Procedia Eng. 2014, 83, 415-422.

(12) Kemiha, M.; Pham Minh, D.; Lyczko, N.; Nzihou, A.; Sharrock, P. Highly porous calcium hydroxyapatite-based composites for air pollution control. Procedia Eng. 2014, 83, 394-402.

(13) Vedrine, J. C.; Millet, J. M. M.; Volta, J. C. Molecular description of active sites in oxidation reactions: Acid-base and redox properties, and role of water. Catal. Today 1996, 32, 115-1230.

(14) Didenko, L. P.; Linde, V. R.; Savchenko, V. I. Partial catalytic oxidation and condensation of methane by oxygen and Sulphur. Catal. Today 1998, 42, 367-370.

(15) Boukha, Z.; Kacimi, M.; Pereira, M. F. R.; Faria, J. L.; Figueiredo, J. L.; Ziyad, M. Methane dry reforming on Ni loaded hydroxyapatite and fluoroapatite. Appl. Catal., A 2007, 317, 299-309.

(16) Gobbitt, J. M. Yara hemihydrate ( $\mathrm{HH})$ and hemidihydrate (HDH) processes for phosphoric acid production. Procedia Eng. 2012, $46,143-153$.

(17) Azaroual, M.; Kervevan, C.; Lassin, A.; André, L.; Amalhay, M.; Khamar, L.; EL Guendouzi, M. Thermo-kinetic and physico-chemical modeling of processes generating scaling problems in phosphoric acid and fertilizers production industries. Procedia Eng. 2012, 46, 68-75.

(18) Pham Minh, D.; Ramaroson, J.; Nzihou, A.; Sharrock, P.; Depelsenaire, G. A new route for the synthesis of alkali polyphosphate from economical starting materials: preparation and characterization of sodium cyclotriphosphate. Phosphorus, Sulfur Silicon Relat. Elem. 2012, $187,112-120$

(19) Pham Minh, D.; Nzihou, A.; Sharrock, P.; Ramaroson, J. A new route for the synthesis of alkali polyphosphate from economical starting materials: Part II-Influence of reaction conditions. Phosphorus, Sulfur Silicon Relat. Elem. 2012, 187, 1132-1140.

(20) Pham Minh, D.; Ramaroson, J.; Nzihou, A.; Sharrock, P. Onestep synthesis of sodium trimetaphosphate $\left(\mathrm{Na}_{3} \mathrm{P}_{3} \mathrm{O}_{9}\right)$ from sodium chloride and orthophosphoric acid. Ind. Eng. Chem. Res. 2012, 51, 3851-3854.

(21) Blumberg, R.; Matitiahu Baniel, A.; Melzer, P. Process for the manufacture of mono-alkali metal phosphates. U.S. 3,393,044, July 16, 1968.

(22) Zhou, J.; Jiao, L.; Su, Y. Ind. Eng. Chem. Res. 1989, 28, 19071910.

(23) Pham Minh, D.; Lyczko, N.; Sebei, H.; Nzihou, A.; Sharrock, P. Mater. Sci. Eng., B 2012, 177, 1080-1089. 